\title{
Thermal behaviour of green façades in summer
}

\author{
Ileana Blanco, Evelia Schettini, Giacomo Scarascia Mugnozza, Giuliano Vox \\ Department of Agricultural and Environmental Science, University of Bari, Italy
}

\begin{abstract}
Building greenery systems can represent a sustainable solution for new buildings design and for existing buildings retrofitting, in order to improve the thermal energy performance of buildings, to decrease building energy loads and to contrast the Urban Heat Island. Green façades can influence thermal properties of a building by means of different important mechanisms: the shading, the cooling, the insulating and the wind barrier effect. Moreover, green façades accomplish heating effect in the cold season and at nighttime. An experimental test was developed at small scale at the University of Bari (Italy) from 2014 to 2016 for testing two different green façades. The plant species chosen were Pandorea jasminoides variegated and Rhyncospermum jasminoides, two evergreen climbing plants. A third uncovered wall was used as control. The thermal behaviour of the plants was analysed during the 2016 summer season, by keeping in consideration the external surface temperature of the building and the temperature of the airgap behind the green vertical systems. The daylight temperatures observed on the plant-covered walls during representative days were lower than the respective temperatures of the uncovered wall up to $7.0^{\circ} \mathrm{C}$. During nighttime, the temperatures behind the plants
\end{abstract}

Correspondence: Evelia Schettini, Department of Agricultural and Environmental Science (DISAAT), University of Bari, via Amendola 165/a, 70126 Bari, Italy.

Tel.: +39.080.5443060 - Fax: +39.080 .5442977 .

E-mail: evelia.schettini@uniba.it

Key words: Vertical greenery; urban heat island; energy savings; Mediterranean climate.

Acknowledgements: the contribution to programming and conducting this research must be equally shared between the Authors. The present work has been carried out under the Piano triennale della Ricerca 2015-2017 nell'ambito del Sistema Elettrico Nazionale, Progetto D.1 Tecnologie per costruire gli edifici del futuro, Research activity: Analisi di tecniche di raffrescamento sostenibili applicabili in edifici civili e in edifici serra, Piano Annuale di Realizzazione (PAR) 2017, Accordo di Programma Ministero dello Sviluppo Economico - ENEA funded by the Italian Ministry of Economic Development.

Received for publication: 18 January 2018.

Accepted for publication: 4 March 2018.

(C) Copyright I. Blanco et al., 2018

Licensee PAGEPress, Italy

Journal of Agricultural Engineering 2018; XLIX:835

doi:10.4081/jae.2018.835

This article is distributed under the terms of the Creative Commons Attribution Noncommercial License (by-nc 4.0) which permits any noncommercial use, distribution, and reproduction in any medium, provided the original author(s) and source are credited. were higher than the respective temperatures of the control wall up to $2.2^{\circ} \mathrm{C}$. The results shown in the present research allow delineating the behaviour of the two plant species during summer in the Mediterranean climate region.

\section{Introduction}

Nowadays, worldwide urban areas are characterized by higher air temperatures in downtown in comparison to the surrounding suburban and rural areas and the air temperature difference can be up to $8^{\circ} \mathrm{C}$ (Hoelscher et al., 2016; Schettini et al., 2016; Vox et al., 2017). This phenomenon of urban warming, commonly called as Urban Heat Island (UHI), is mainly due to the presence of building surfaces and pavement, made with water-resistant and lowreflective construction materials that absorb the incident solar radiation and release it as heat during nighttime (Vox et al., 2016). UHI leads to several negative consequences, including bad outdoor comfort conditions and an increased use of building air conditioning systems that results in an excessive energy consumption for cooling, typically satisfied with fossil energy sources (Karlessi et al., 2011; Vox et al., 2014; Blanco et al., 2017).

Building greenery systems, as other urban green infrastructures, can be efficiently applied in order to contrast the UHI effect by mitigating the frequency and magnitude of the related heat events. The use of greenery systems on buildings is useful to reduce the outdoor and indoor temperatures, but also to improve human thermal comfort and to decrease energy loads of buildings (Cameron et al., 2014; Pérez et al., 2014; Norton et al., 2015). Building greenery systems, also recently called building-integrated vegetation (Giordano et al., 2017), in relation to the building surface where greeneries can be placed are distinguished in vertical greening and green roofs, green balconies, sky gardens, and indoor sky gardens. In dense urban areas, characterized by scarce green areas and limited open ground space, vertical greening systems represent an innovative and promising chance for increasing and spreading the green infrastructures. The increasingly growing research on vertical greening proves the importance of green in urban environments and the necessity to deepen such a multidisciplinary issue.

Vertical greening systems, also commonly referred to as green wall or vertical garden, are those systems that permit greening a vertical surface. They can be firstly classified into two categories depending on the growing method, the vegetation type, and the support structure: green façades and living walls (PérezUrrestarazu et al., 2016; Medl et al., 2017).

Green façades are ground-based greening methods with plants rooted in the ground at the base of buildings, or in planters at different heights of the façade, or even on the rooftop. Green façades are classified as direct or indirect due to the absence or presence of a support, respectively. In the direct greening façades plants climb directly on the façade of the building through morphologi- 
cal features, such as aerial roots, leaf tendrils and adhesion pads, without any added support. Indirect greening façades are characterised by plants that climb on a structural support, such as wire, mesh, trellis, located to a small distance to the wall or on a freestanding system, such as fence or column (Kontoleon and Eumorfopoulou, 2010).

Living walls are wall-based greening methods (Medl et al., 2017), composed of pre-cultivated modular panels or planted bags, containing a growing medium (soil, foam, felt, mineral wood, perlite) and an irrigation system, fixed to a wall or free-standing frame (Perini et al., 2011; Cameron et al., 2014; Pérez et al., 2014; Raji et al., 2015; Giordano et al., 2017).

With respect to a living wall system, a green façade is characterized by a smaller selection of plants; it has fewer variables to manage in relation to the supporting structure, the nutrients and watering system management. It is therefore a cheaper solution, easy to maintain, and requires little energy (Perini et al., 2011).

Greening systems provide several benefits, such as environmental, economic, social and aesthetical benefits, that are influenced by the urban framework, climatic area, greening system design and the characteristics of the building (Francis and Lorimer, 2011; Perini et al., 2011). As well as building greenery systems, also green façades could contribute to benefits at local and at urban scale, in particular on the walls, on the building and on its surrounding urban environment. The benefits on the wall are: an increment of wall thermal insulation, an extension of its lifetime, a reduction of solar and noise absorbance. The benefits produced on the building are: decrease of heat load and of energy consumption, improvement of the indoor thermal and acoustic comfort, enhancement of the commercial value of the real estate. The benefits at a larger scale are: UHI effect mitigation, energy consumption reduc- tion, air pollution mitigation and oxygen production; enhancement of stormwater management, of water run-off quality, of urban hydrology, of the use of rainwater; sound absorption; urban biodiversity preservation.

The thermal properties of a building with green façades are influenced by several mechanisms (Hunter et al., 2014; Perez et al., 2014; Jim, 2015): insulation capacity of the components constituting the system, function of the plant layer and of the air gap between the wall and the plant layer; shading capacity of the plants to intercept the solar radiation; cooling effect due to the water evapotranspiration process from the plants and substrates; wind barrier effect due to the modification of air speed and direction on buildings provided by the plants and to alteration of the air renovation in the green façades layers. Moreover, green façades accomplish heating effect inducing indoor warming in the cold season and at nighttime, due to the thermal-mass effect of the substrate and of the plants, to the reduction of the longwave infrared radiation losses from building wall towards outside and to the reduction of the convective losses.

Available literature reports several different microclimate and building thermal behaviour parameters for assessing the effects of green façades on building thermal performance. The thermal performance parameter most commonly analysed is the external wall surface temperature of the building or prototype, which strongly influences the building microclimate.

The thermal effectiveness of the vertical greenery systems in summer requires further investigation with reference to the different climates for its dependence on the climatic conditions, in order to fill in the gaps in the literature. The aim of this paper is to analyse the thermal performance of two different green façades in summer in the Mediterranean region. Two experimental green façades

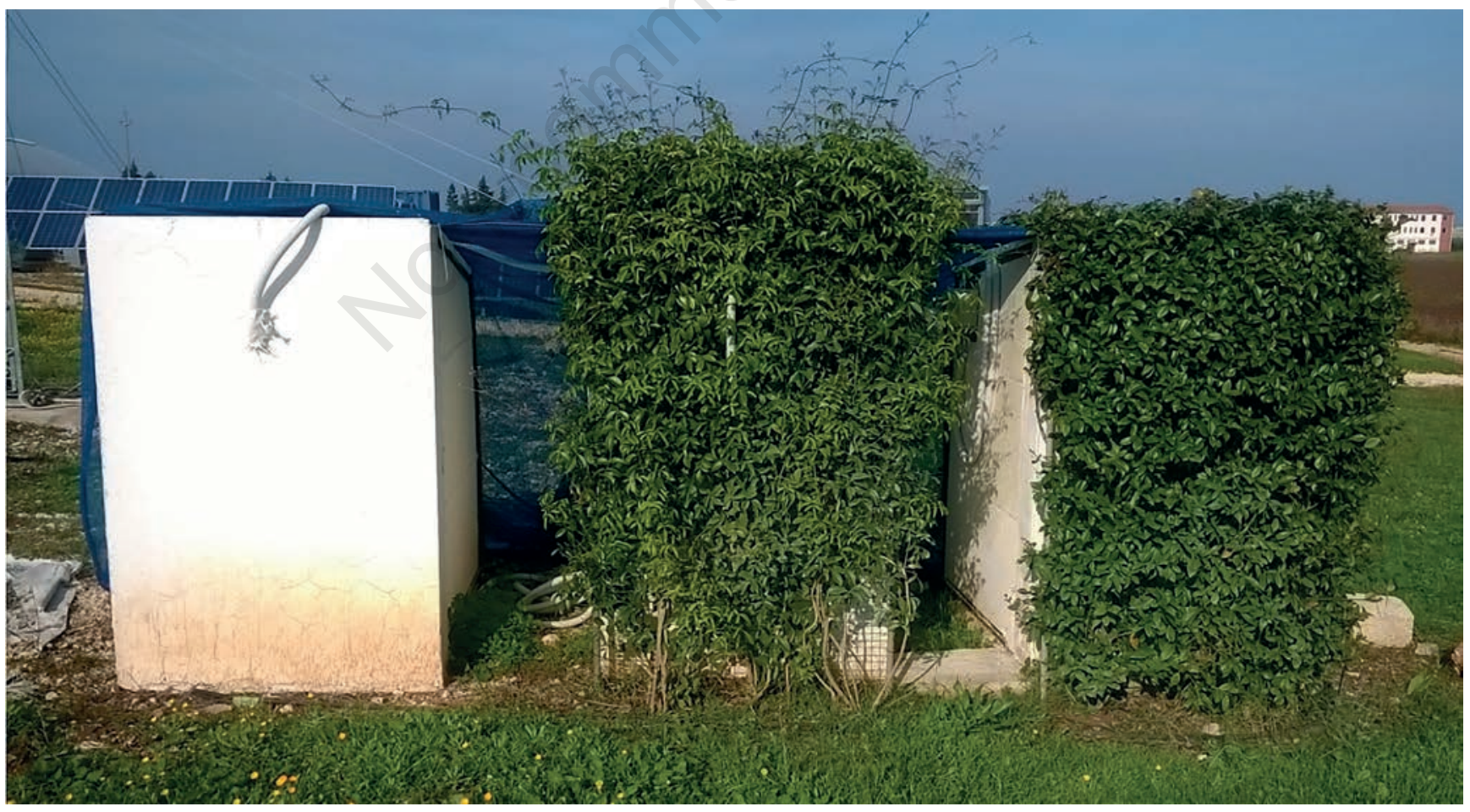

Figure 1. The three walls at the experimental field of the University of Bari; the central wall is screened with Pandorea jasminoides variegated, the right wall with Rhyncospermum jasminoides, and the left wall is the control wall. 
were tested at small scale at the University of Bari, South Italy, and the variations of the external surface temperature of the walls equipped with the greenery systems were reported. Statistical analyses were carried out to identify significant differences between the walls surface, the air-gap and the external air temperatures.

\section{Materials and methods}

A research was developed from June 2014 to December 2016 at the experimental field of the University of Bari in Valenzano (Bari, Italy) at latitude $41^{\circ} 05^{\prime} \mathrm{N}$, longitude $16^{\circ} 53^{\prime} \mathrm{E}$, altitude $85 \mathrm{~m}$ a.s.1. The climate of the site is classified as Csa, i.e. Mediterranean climate, according to the Kopper-Geiger climate classification (Kottek et al., 2006).

Three south oriented walls were built with a typical Mediterranean building solution, i.e. a single skin of perforated bricks joined with mortar (Figure 1), in order to simulate common building walls. A sealed structure, made of sheets of expanded polystyrene, was built on the backside of each wall for shading and insulating the internal side (north exposed) of the walls (Figure 2). The sealed structure was furthermore shaded by a net positioned on it for reducing the incident solar radiation effect.

Each wall was characterised by a width of $1.00 \mathrm{~m}$, a height of $1.55 \mathrm{~m}$, and a total thickness of $0.22 \mathrm{~m}$ (the thickness of the masonry was $0.20 \mathrm{~m}$ plus a thickness of the plaster coating equal to 0.02 $\mathrm{m})$. The thermal conductivity coefficients of the masonry and of the plaster coating were $0.28 \mathrm{Wm}^{-1} \mathrm{~K}^{-1}$ and $0.55 \mathrm{Wm}^{-1} \mathrm{~K}^{-1}$, respectively (UNI EN 1745, 2012). The heat capacity coefficients of the masonry and of the plaster coating were $840 \mathrm{Jkg}^{-1} \mathrm{~K}^{-1}$ and 1000 $\mathrm{Jkg}^{-1} \mathrm{~K}^{-1}$, respectively. The average density of the walls, including plaster, was equal to $695 \mathrm{~kg} \mathrm{~m}^{-3}$.

The planted species are Pandorea jasminoides variegated and Rhyncospermum jasminoides, two evergreen climber plants, well adapting to the climatic conditions of the experimental area. Pandorea jasminoides variegated and Rhyncospermum jasmi- noides were transplanted on June 18, 2014. A third uncovered wall was kept for control. An iron net was placed at a distance of $15 \mathrm{~cm}$ from the wall for supporting the plant vertical growth. The irrigation method used was the drip system and fertilization was performed with a N:P:K 12:12:12 fertilizer.

Plant leaf area index (LAI) was measured with a AccuPAR PAR/LAI Ceptometer (model LP-80, Decagon Devices Inc., Pullman, WA, USA); it varies throughout the year between 2.0-4.0 for Rhyncospermum jasminoides and 1.5-3.5 for Pandorea jasminoides variegated.

The external air temperature and relative humidity, the temperature of the plaster on the external surface of the walls, the air temperature in the gap between the walls and the plant layers and the solar radiation on a horizontal and on a vertical plane were measured during the test. The above-mentioned parameters were measured with a frequency of $60 \mathrm{~s}$, and were averaged every $15 \mathrm{~min}$; data were stored on a data logger (CR10X, Campbell, Logan, USA).

The air temperature and relative humidity were measured by Hygroclip-S3 sensors (Rotronic, Zurich, Switzerland); the temperature of the external plaster surfaces was measured using thermistors (Tecno.EL s.r.l. Formello, Rome, Italy). All sensors were shielded from solar radiation. The solar radiation on a horizontal and on a vertical plane were measured in the wavelength range 0.3 $3.0 \mathrm{~mm}$ by means of pyranometer (model 8-48, Eppley Laboratory, Newport, RI, USA). Wind speed was measured by Young Wind Sentry anemometer (Young Company, Traverse City, MI, USA).

Analysis of variance (ANOVA) was developed with the CoStat software (CoHort Software, Monterey, CA, USA) to identify significant differences between the temperature data. The monthly values of the climatic parameters measured during 2016 at the experimental field in Valenzano are reported in Table 1. During 2016 the field was characterized by values of the external air temperature ranging from $0.7^{\circ} \mathrm{C}$ (December) to $39.2^{\circ} \mathrm{C}$ (August). The monthly value of cumulative solar radiation on a horizontal plane ranged from $177 \mathrm{MJ} \mathrm{m}^{-2}$ (January) to $760 \mathrm{MJ} \mathrm{m}^{-2}$ (July), and the yearly cumulative solar radiation was equal to $5129 \mathrm{MJ} \mathrm{m}^{-2}$.

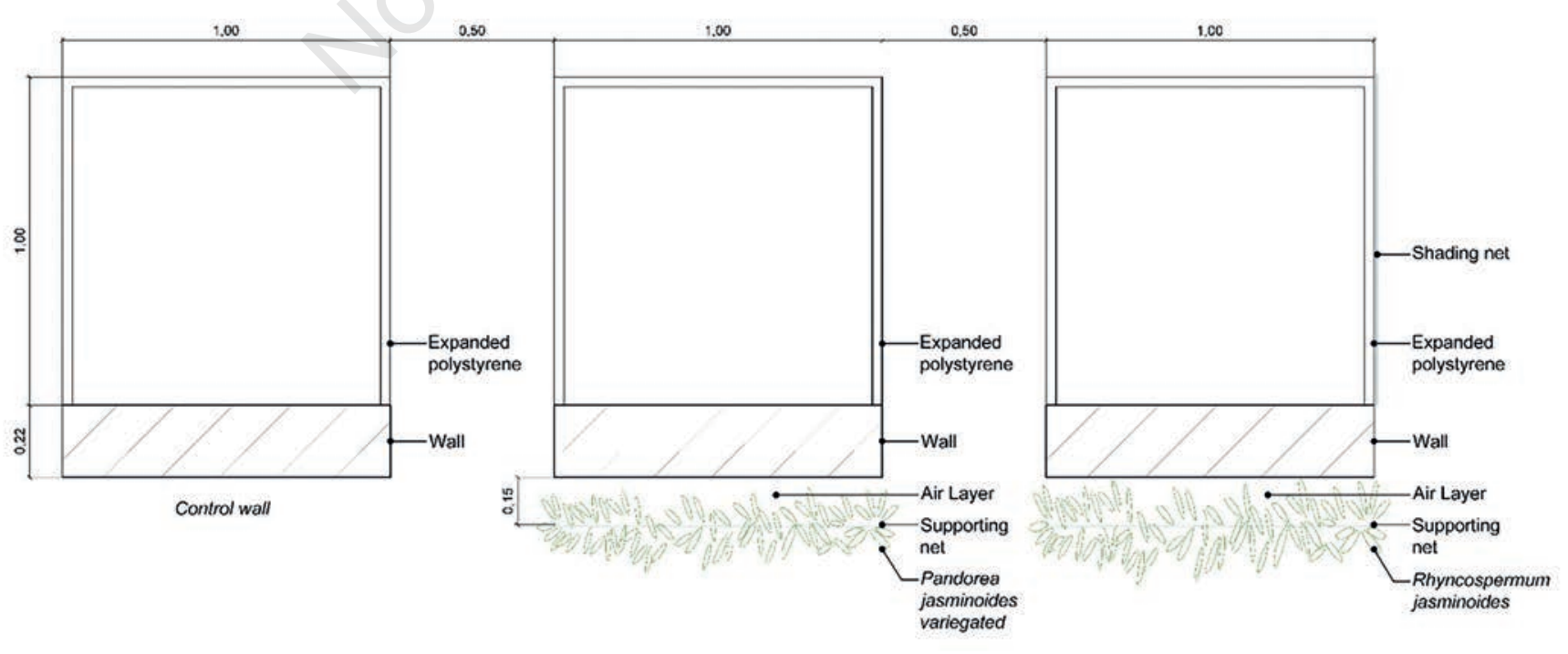

Figure 2. Schematic plan of the experimental walls. 


\section{Results}

The influence of the climatic conditions on the cooling performance of the green façades was analysed by considering representative days of the summer 2016. Three days (28/06/2016, $23 / 07 / 2016$, and $27 / 08 / 2016$ ) were chosen because they were characterised by an hourly evolution of the external air temperatures on the average of June, July and August, respectively. The thermal behaviour of the green façades under different weather conditions (cloudy days) was evaluated in Vox et al. (2018).

Plant LAI reached its maximum values during the summer season, ranging from 3.5 to 4.0 for Rhyncospermum jasminoides and from 3.0 to 3.5 for Pandorea jasminoides variegated.

Figures 3-5 show the external air temperature, the wall external surface temperature of the three walls, the air-gap temperature

Table 1. Climatic data of the experimental field in Valenzano (Bari) in 2016 (data obtained from the weather station at the experimental site; the mean values were calculated as the arithmetic means of the values collected throughout the months; the maximum and minimum values are respectively the highest and lowest values collected in every month).

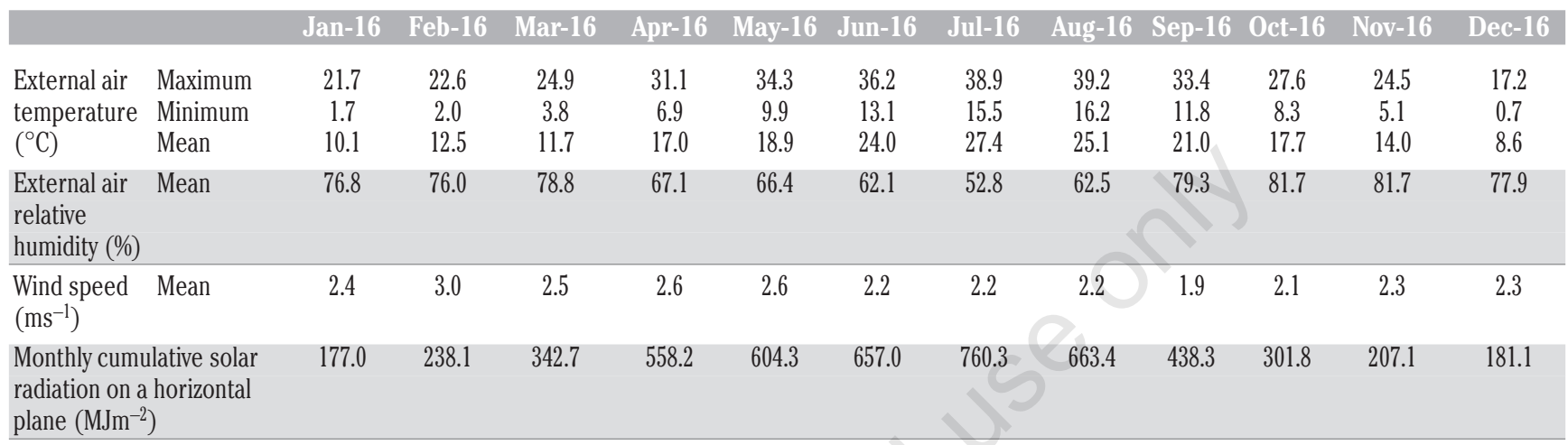

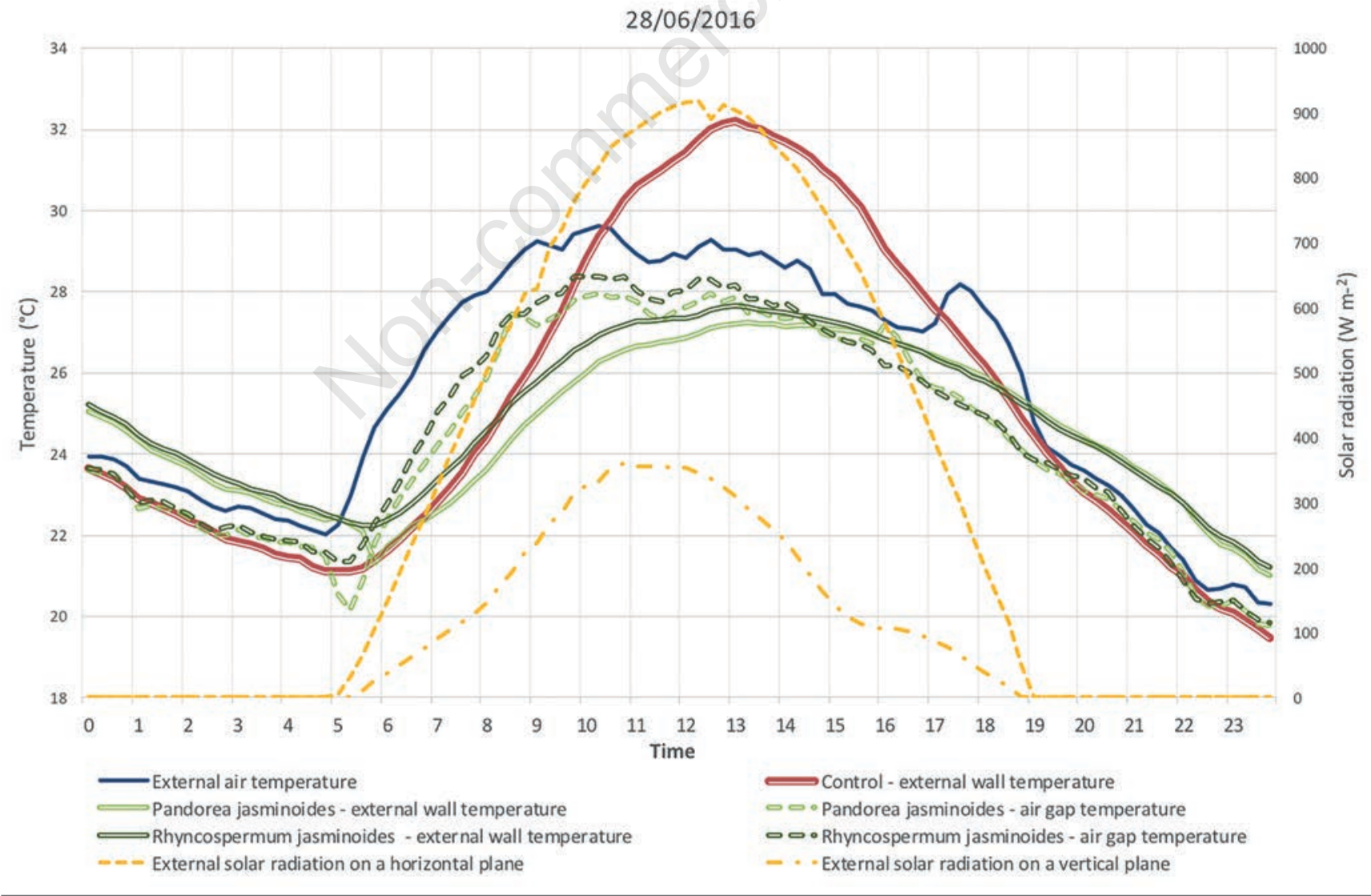

Figure 3. External air temperature, surface temperature of the external plaster of the three walls, air gap temperature behind the two green layers, and solar radiation on a horizontal and on a vertical plane (secondary axis) on 28 June 2016. 
behind the two green layers and the solar radiation on a horizontal and on a vertical plane for the three selected days.

As shown in Figure 3, during 28/06/2016, the wall external surface temperature of the control rose in the morning in synch with the solar radiation values more than the temperature of the external side of the walls screened by the plants. Vox et al. (2018) have found that a threshold value of the horizontal solar radiation of about $200 \mathrm{Wm}^{-2}$ is necessary for arousing a cooling effect by the green façades on the wall external surfaces. Indeed, in correspondence of values of the horizontal solar radiation higher than 200 $\mathrm{Wm}^{-2}$, data in Figure 3 show that the external wall temperature of the green façades was on average lower than the external wall temperature of the control wall. During daytime, when the horizontal solar radiation exceeded the threshold value of about $200 \mathrm{Wm}^{-2}$, the wind velocity values varied in the range $1.5-5.5 \mathrm{~ms}^{-1}$, with a mean value of $3.7 \mathrm{~ms}^{-1}$. During the hot hours of the day, the mitigation of the wall external surface temperatures of the two green façades, in comparison with those of the control wall, was remarkable. A reduction in the intensity of solar radiation leads to the decrease of these differences. The maximum reduction of temperature between the control wall without greening and the covered ones was registered between 12:45 and 13:00 $\mathrm{h}$ for the wall screened with Pandorea jasminoides variegated and it was equal to $5.0^{\circ} \mathrm{C}$. On the other hand, the heating effect due to the application of the green layers led to increase the wall external surface temperature up to $1.8^{\circ} \mathrm{C}$ at night (around 22:00 h) for both the two plant species. The air-gap temperatures always followed the hourly evolution of the external ambient air temperature but always remaining below it and having a smaller temperature fluctuation than the external air (Figure 3).

During 23/07/2016, the maximum reduction of temperature between the control wall and the plant-covered ones was registered between 13:00 and 13:15 $\mathrm{h}$ for the wall screened with Rhyncospermum jasminoides and it was equal to $6.3^{\circ} \mathrm{C}$ (Figure 4). During daytime, the wind velocity values varied from 0.3 to 3.6 $\mathrm{ms}^{-1}$, with a mean value of $2.1 \mathrm{~ms}^{-1}$. On the other hand, the heating effect due to the application of the green layers led to increase the wall external surface temperature up to $2.2^{\circ} \mathrm{C}$ at night (around 1:30 h) for Rhyncospermum jasminoides. The air-gap temperatures always followed the hourly evolution of the external ambient air temperature; it always remained below it for Rhyncospermum jasminoides, while it had similar values to the external ambient air temperature only between noon and 17:00 h for Pandorea jasminoides variegated (Figure 4).

During 27/08/2016, the maximum reduction of temperature between the control wall and the plant-covered ones was registered between 13:00 and 13:15 $\mathrm{h}$ for the wall screened with Rhyncospermum jasminoides and it was equal to $7.0^{\circ} \mathrm{C}$ (Figure 5). During daytime, the wind velocity values varied in the range 0.5 $3.2 \mathrm{~ms}^{-1}$, with a mean value of $2.2 \mathrm{~ms}^{-1}$. On the other hand, the heating effect due to the application of the green layers led to increase the wall external surface temperature up to $1.7^{\circ} \mathrm{C}$ at night (around 22:30 h) for Pandorea jasminoides variegated. The airgap temperatures mainly followed the hourly evolution of the

\section{$23 / 07 / 2016$}

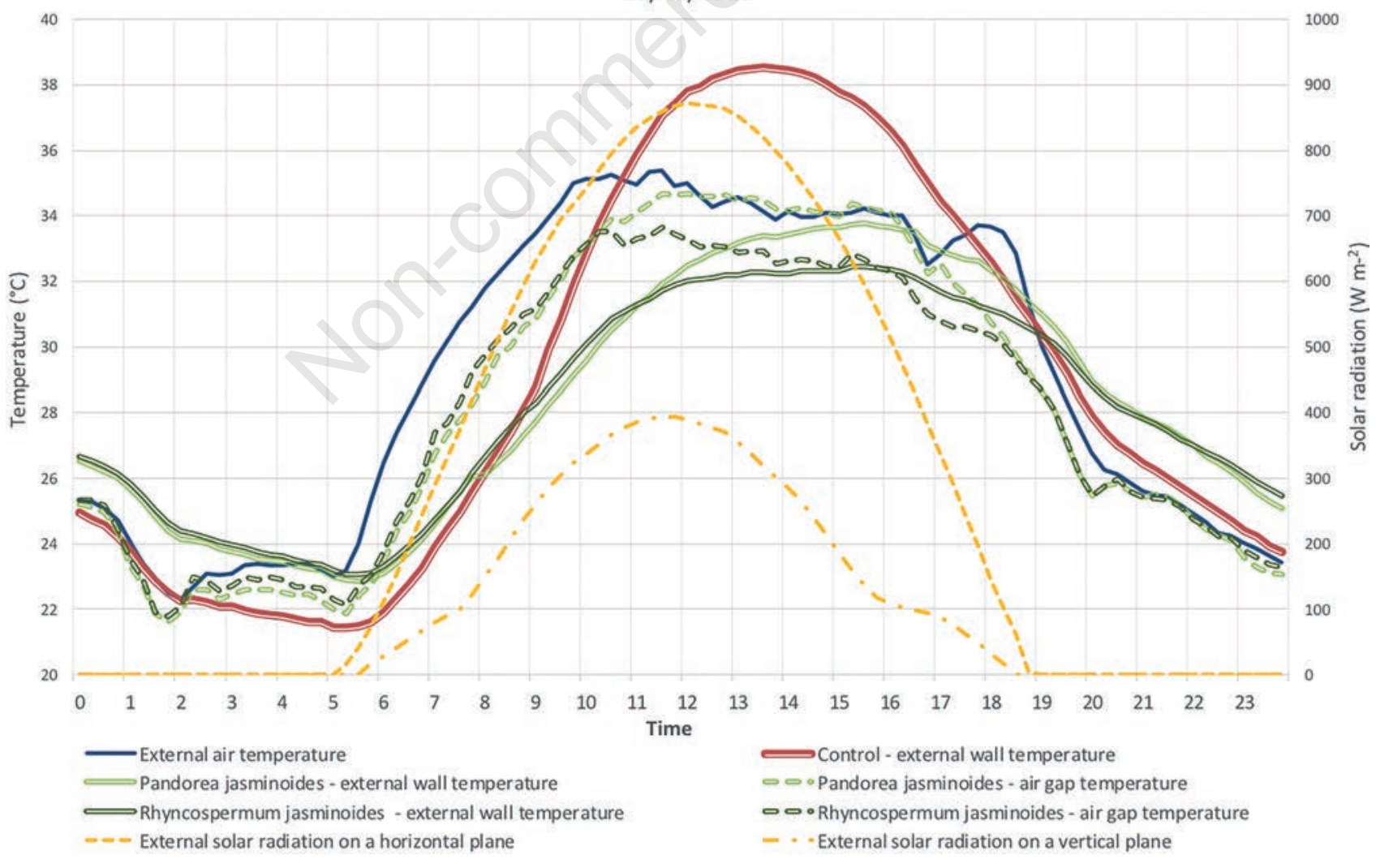

Figure 4. External air temperature, surface temperature of the external plaster of the three walls, air gap temperature behind the two green layers, and solar radiation on a horizontal and on a vertical plane (secondary axis) on 23 July 2016. 
external ambient air temperature; it always remained below it for Rhyncospermum jasminoides. The air-gap temperatures for Pandorea jasminoides variegated had frequently similar values to the external ambient air temperature while they were higher between 10:00 and 18:00 $\mathrm{h}$ (Figure 5).

The different behaviour in changing the wall external surface temperature among the three days can be traced back to the increasing values of solar radiation incident on the vertical plane (Figures 3-5) as the summer months progress and thus, to the attitude of the green walls to act as direct solar radiation shield.

One-way ANOVA analysis at a $95 \%$ probability level was performed for the selected days of the testing period in order to compare the daily mean values of the external air temperature, external surface temperature of the three experimental walls and air-gap temperatures, once the horizontal solar radiation exceeded the threshold value of about $200 \mathrm{Wm}^{-2}$. Statistically significant differences at $\mathrm{P}<0.001$ were found, thus Duncan's test was applied with a significance level equal of 0.05 . The differences among the external surface temperature of three walls were evaluated in Table 2. The mean values of the surface temperatures recorded on the two green façades were statistically similar to each other; they also resulted to be lower than the values recorded on the control wall during all the daytime, demonstrating the persistence of the cooling effect during daytime hours.

The differences among the external air, air-gap temperature and external wall surface temperature of the two green façades were also evaluated (Tables 3 and 4). Concerning Rhyncospermum jasminoides, the mean value of the temperature of the air in the gap comprised between the wall and the plant layer was statistically lower than the mean value of the external air temperature and higher than the mean value of the external wall surface temperature during the three selected days (Table 3). Concerning Pandorea jasminoides variegated, the air-gap temperature showed a different performance in 23/07/2016 and 27/08/2016 remaining statistically similar to the external air temperature and higher than the external surfaces ones (Table 4).

The experimental results on the air-gap temperature of Rhyncospermum jasminoides are in agreement with the findings of Chen et al. (2013) and Pérez et al. (2011) which assessed the ability of the green façades to create a behind-green layer microclimate, characterized by lower air temperature than the external one during daytime of summer sunny days.

\section{Conclusions}

Vertical greenery systems can be used as passive technologies for enhancing the energy efficiency of buildings thanks to their ability to act as a thermal screen and to create natural shading. The assessment of the thermal behaviour of green façades in several climate scenarios is necessary to define the solutions that make the

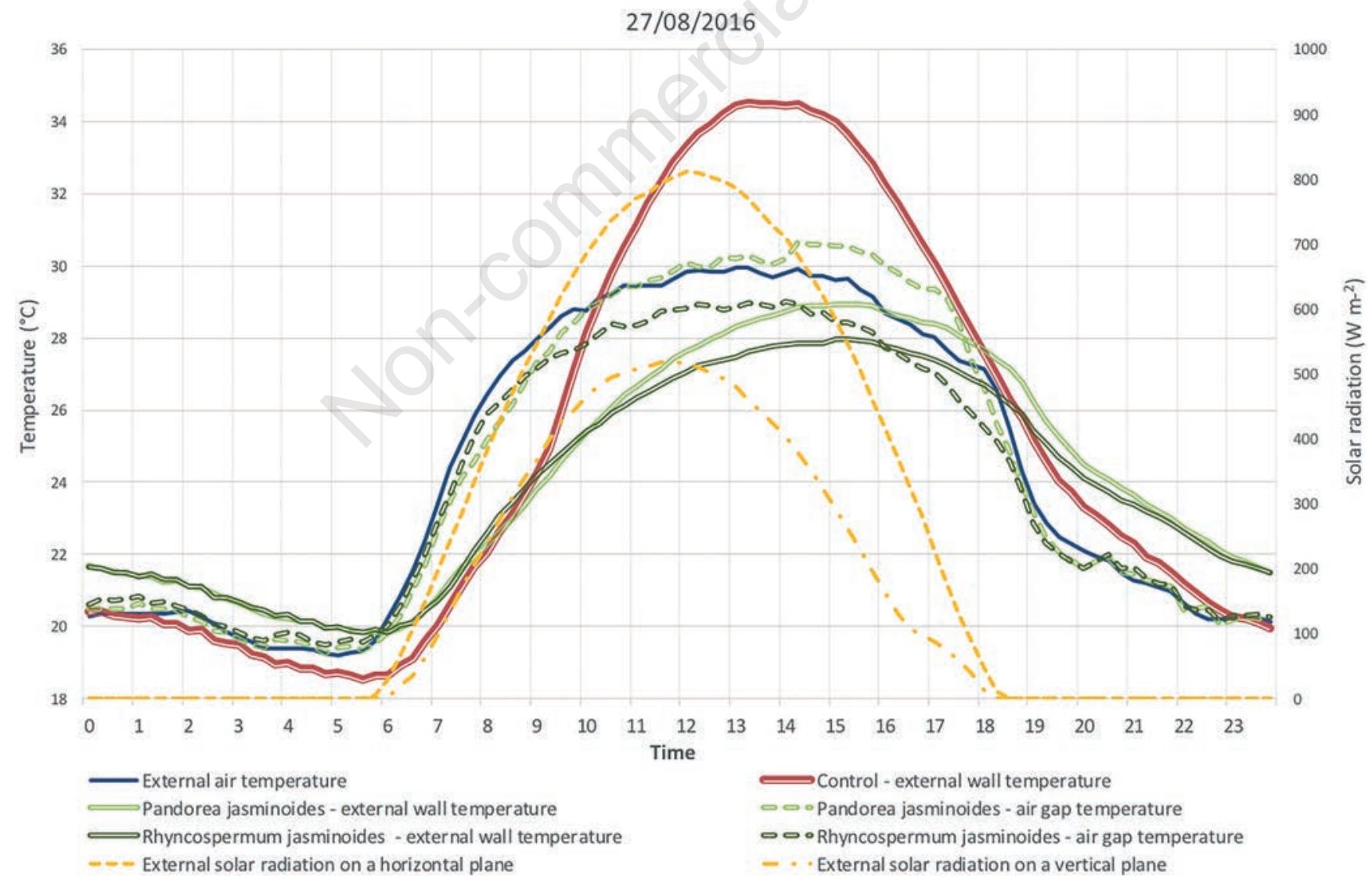

Figure 5. External air temperature, surface temperature of the external plaster of the three walls, air gap temperature behind the two green layers, and solar radiation on a horizontal and on a vertical plane (secondary axis) on 27 August 2016. 
most of their potential.

In this research, two green façades were studied with reference to their cooling effect in Mediterranean climatic conditions. The thermal operation of two different climbing plants, Rhyncospermum jasminoides and Pandorea jasminoides variegat$e d$, was analysed during three representative days of the 2016 summer season, by keeping in consideration the external surface temperature of the building and the temperature of the air-gap behind the green vertical systems.

The application of the green layer reduced wall surface tem-

Table 2. Mean values of the surface temperature of the external plaster of the three walls during 28/06/2016, 23/07/2016 and $27 / 08 / 2016$ once the horizontal solar radiation exceeded the threshold value of about $200 \mathrm{Wm}^{-2}$ (the mean values were calculated as the arithmetic means of the values collected throughout the days).

\begin{tabular}{lccc} 
& \multicolumn{3}{c}{ Mean temperature $\left({ }^{\circ} \mathrm{C}\right)$} \\
& $28 / 06 / 2016$ & $23 / 07 / 2016$ & $27 / 08 / 2016$ \\
Control & $28.51^{\mathrm{a}}$ & $33.84^{\mathrm{a}}$ & $30.06^{\mathrm{a}}$ \\
Rhyncospermum jasminoides & $26.35^{\mathrm{b}}$ & $30.44^{\mathrm{b}}$ & $26.16^{\mathrm{b}}$ \\
\hline Pandorea jasminoides & $25.92^{\mathrm{b}}$ & $30.90^{\mathrm{b}}$ & $26.61^{\mathrm{b}}$ \\
\hline
\end{tabular}

${ }^{\mathrm{a}-\mathrm{b}}$ Mean values of the temperature in each column with a different superscript letter statistically differ at $\mathrm{P}<0.05$ using Duncan's test.

Table 3. Mean values of the temperature of the external air, surface of the external plaster and air gap of the Rhyncospermum jasminoides green façade during 28/06/2016, 23/07/2016 and $27 / 08 / 2016$ once the horizontal solar radiation exceeded the threshold value of about $200 \mathrm{Wm}^{-2}$ (the mean values were calculated as the arithmetic means of the values collected throughout the days).

\begin{tabular}{|c|c|c|c|}
\hline & $\begin{array}{r}\text { Mea } \\
28 / 06 / 2016\end{array}$ & $\begin{array}{l}\text { temperature } \\
23 / 07 / 2016\end{array}$ & $\begin{array}{l}\left({ }^{\circ} \mathrm{C}\right) \\
27 / 08 / 2016\end{array}$ \\
\hline External air & $28.32^{\mathrm{a}}$ & $33.62^{\mathrm{a}}$ & $28.73^{\mathrm{a}}$ \\
\hline $\begin{array}{l}\text { Rhyncospermum } \\
\text { jasminoides - air gap }\end{array}$ & $26.97^{\mathrm{b}}$ & $31.79^{b}$ & $27.81^{\mathrm{b}}$ \\
\hline $\begin{array}{l}\text { Rhyncospermum jasminoides - } \\
\text { external wall }\end{array}$ & $-26.35^{c}$ & $30.44^{c}$ & $26.16^{\mathrm{c}}$ \\
\hline
\end{tabular}

Table 4. Mean values of the temperature of the external air, surface of the external plaster and air gap of the Pandorea jasminoides variegated green façade during 28/06/2016, 23/07/2016 and $27 / 08 / 2016$ once the horizontal solar radiation exceeded the threshold value of about $200 \mathrm{Wm}^{-2}$ (the mean values were calculated as the arithmetic means of the values collected throughout the days).

\begin{tabular}{lccc} 
& \multicolumn{3}{c}{ Mean temperature $\left({ }^{\circ} \mathrm{C}\right)$} \\
& $28 / 06 / 2016$ & $23 / 07 / 2016$ & $27 / 08 / 2016$ \\
External air & $28.32^{\mathrm{a}}$ & $33.62^{\mathrm{a}}$ & $28.73^{\mathrm{a}}$ \\
Pandorea jasminoides - air gap & $26.72^{\mathrm{b}}$ & $32.67^{\mathrm{a}}$ & $28.89^{\mathrm{a}}$ \\
\hline Pandorea jasminoides - & $25.92^{\mathrm{c}}$ & $30.90^{\mathrm{b}}$ & $26.61^{\mathrm{b}}$
\end{tabular}

external wall

a-cMean values of the temperature in a column with a different superscript letter statistically differ at $\mathrm{P}<0.05$ using Duncan's test. peratures during days representative of the period up to $5.0-7.0^{\circ} \mathrm{C}$. However, at nighttime, temperatures of the external side of the vegetated walls were warmer than the control wall ones up to 1.7$2.2^{\circ} \mathrm{C}$

The presence of an air gap between the building façade and the Rhyncospermum jasminoides layer is able to act as thermal buffer, improving thermal insulation impact of the building.

\section{References}

Blanco I., Schettini E., Scarascia Mugnozza G., Campiotti C.A., Giagnacovo G., Vox G. 2017. Vegetation as a passive system for enhancing building climate control. Acta Hortic. 1170:555-62.

Cameron R.W.F., Taylor J.E., Emmett M.R. 2014. What's 'cool' in the world of green façades? How plant choice influences the cooling properties of green walls. Build. Environ. 73:198-207.

Chen Q., Li B., Liu X. 2013. An experimental evaluation of the living wall system in hot and humid climate. Energ. Build. 61:298-307.

Francis R.A., Lorimer J. 2011. Urban reconciliation ecology: the potential of living roofs and walls. J. Environ. Manage. 92:1429-37.

Giordano R., Montacchini E., Tedesco S., Perone A. 2017. Living wall systems: a technical standard proposal. Ener. Procedia 111:298-307.

Hoelscher M.T., Nehls T., Jänicke B., Wessolek G. 2016. Quantifying cooling effects of facade greening: Shading, transpiration and insulation. Energ. Build. 114:283-90.

Hunter A.M., Williams N.S.G., Rayner J.P., Aye L., Hes D., Livesley S.J. 2014. Quantifying the thermal performance of green façades: a critical review. Ecol. Eng. 63:102-13.

Jim C.Y. 2015. Thermal performance of climber greenwalls: Effects of solar irradiance and orientation, Appl. Energy 154:631-43.

Karlessi T., Santamouris M., Synnefa A., Assimakopoulos D., Didaskalopoulos P., Apostolakis K. 2011. Development and testing of PCM doped cool colored coatings to mitigate urban heat island and cool buildings. Build. Environ. 46:570-6.

Kontoleon K.J., Eumorfopoulou E.A. 2010. The effect of the orientation and proportion of a plant-covered wall layer on the thermal performance of a building zone. Build. Environ. 45:1287-303.

Kottek M., Grieser J., Beck C., Rudolf B., Rubel F. 2006. World Map of the Köppen-Geiger climate classification updated. Meteorol. Zeitschr. 15:259-63.

Medl A., Stangl R., Florineth F. 2017. Vertical greening systems a review on recent technologies and research advancement, Build. Environ. 125:227-39.

Norton B.A., Coutts A.M., Livesley S.J., Harris R.J., Hunter A.M., Williams N.S.G. 2015. Planning for cooler cities: A framework to prioritise green infrastructure to mitigate high temperatures in urban landscapes. Landsc. Urban Plan. 134:127-38.

Pérez G., Coma J., Martorell I., Cabeza L.F. 2014. Vertical Greenery Systems (VGS) for energy saving in buildings: a review. Renew. Sust. Energ. Rev. 39:139-65.

Pérez G., Rincón L., Vila A., González J.M., Cabeza L.F. 2011. Green vertical systems for buildings as passive systems for energy savings. Appl. Energy 88:4854-9.

Pérez-Urrestarazu L., Fernández-Cañero R., Franco-Salas A., Egea G. 2016. Vertical greening systems and sustainable cities. J. Urban Technol. 22:65-85. 
Perini K., Ottelé M., Fraaij A.L.A., Haas E.M., Raiteri R. 2011. Vertical greening systems and the effect on airflow and temperature on the building envelope. Build. Environ. 46:2287-94.

Raji B., Tenpierik M.J., Van Den Dobbelsteen A. 2015. The impact of greening systems on building energy performance: a literature review. Renew. Sust. Energ. Rev. 45: 610-23.

Schettini E., Blanco I., Campiotti C.A., Bibbiani C., Fantozzi F., Vox G. 2016. Green control of microclimate in buildings. Agric. Agric. Sci. Proc. 8:576-82.

UNI EN 1745 2012. Masonry and masonry products - Methods for determining thermal properties. UNI - Ente Nazionale Italiano di Unificazione - Italian Organization for Standardization, Rome, Italy.

Vox G., Blanco I., Fuina S., Campiotti C.A., Scarascia Mugnozza,
G., Schettini, E. 2017. Evaluation of wall surface temperatures in green facades. Proc. Inst. Civil Engine. - Engine. Sustain. 170:334-44.

Vox G., Blanco I., Scarascia Mugnozza G., Schettini E., Bibbiani C., Viola C., Campiotti C. A. 2014. Solar absorption cooling system for greenhouse climate control: technical evaluation. Acta Hortic. 1037:533-8.

Vox G., Blanco I., Schettini E. 2018. Green façades to control wall surface temperature in buildings. Build. Environ. 129:154-66.

Vox G., Maneta A., Schettini E. 2016. Evaluation of the radiometric properties of roofing materials for livestock buildings and their effect on the surface temperature. Biosyst. Engine. 144:26-37. 